\title{
FACING TRANSLATION ERRORS AT INTERNATIONAL ORGANIZATIONS: WHAT CORRIGENDA REVEAL ABOUT CORRECTION PROCESSES AND THEIR IMPLICATIONS FOR TRANSLATION QUALITY
}

\section{FERNANDO PRIETO RAMOS, Prof.}

Centre for Legal and Institutional Translation Studies (Transius) Faculty of Translation and Interpreting, University of Geneva Uni Mail, 40 Bd du Pont-d'Arve 1211 Geneva 4, Switzerland fernando.prieto@unige.ch

ORCID: https://orcid.org/0000-0002-4314-2813

\begin{abstract}
Corrigenda issued by international organizations provide a most relevant source for the analysis of translation errors and what they reveal about institutional translation quality control and correction processes. This study examines corrigenda published in three settings (the European Union institutions involved in law-making, the United Nations and the World Trade Organization) in three years over a decade: 2005, 2010 and 2015. It reviews the procedures used to introduce translation corrections in these institutions
\end{abstract}


before presenting the results of the quantitative and qualitative analysis of translation-triggered corrigenda in two target languages, French and Spanish, per setting, year, genre, error type and severity. A distinction is made between content reformulation corrections and minor formal corrections for the comparison of diachronic changes and semantic impact levels of corrected errors between the institutions considered. The findings confirm that minor formal errors may have meaning-distorting effects that are as serious as content reformulation errors; when this is not the case, they rarely trigger singlecorrection corrigenda. The UN recourse to "reissues for technical reasons" for translation corrections and the growing number of corrigenda to EU legal acts and their implications for translation quality assurance and legal certainty are further contextualized and discussed drawing on both corpus analysis and consultations with institutional informants.

Keywords: corrigenda; translation errors; translation corrections; translation quality assurance; institutional translation; international organizations; EU institutions; legal certainty.

\title{
W OBLICZU BŁĘDÓW TŁUMACZENIOWYCH W INSTYTUCJACH MIĘDZYNARODOWYCH: CO SPROSTOWANIA MÓWIĄ O PROCESIE DOKONYWANIA POPRAWEK I ICH WPLYW NA JAKOŚĆ PRZEKLADU
}

\begin{abstract}
Abstrakt: Sprostowania wydawane przez organizacje międzynarodowe stanowią najistotniejsze źródło analizy błędów w tłumaczeniu oraz tego, co ujawniają na temat instytucjonalnej kontroli jakości tłumaczeń i procesów korekty. W niniejszym badaniu przeanalizowano sprostowania opublikowane przez trzy instytucje (Unię Europejską zaangażowaną w stanowienie prawa, ONZ i Światową Organizację Handlu) na przestrzeni dekady w latach: 2005, 2010 i 2015 r. Najpierw dokonano przeglądu procedur zastosowanych do wprowadzenia poprawek do thumaczeń w tych instytucjach. Następnie przedstawiono wyniki analizy ilościowej i jakościowej sprostowań thumaczeń w dwóch językach docelowych, francuskim i hiszpańskim, według instytucji, roku, gatunku, rodzaju błędu i jego wagi. Wprowadzono rozróżnienie między zmianami wpływającymi na treść komunikatu a drobnymi poprawkami formalnymi $\mathrm{w}$ celu porównania zmian diachronicznych i rodzaju zmian semantycznych, wynikających z korekty błędów wprowadzanych przez poszczególne instytucje. Ustalenia potwierdzają, że drobne błędy formalne mogą mieć równie poważne skutki, zniekształcające znaczenie, jak błędy zmieniające treść komunikatu; w wypadkach odmiennych rzadko dochodzi do wydania jakiegokolwiek sprostowania błędu. Autor kontekstualizuje i omawia podejście ONZ do ,ponownego publikowania $\mathrm{z}$ przyczyn technicznych tekstów" uwzględniających poprawione błędy tłumaczeniowe
\end{abstract}


oraz rosnącą liczbę sprostowań aktów prawnych UE i ich konsekwencje dla zapewnienia jakości tłumaczeń oraz pewności prawa w oparciu o analizę korpusu i konsultacje z informatorami instytucjonalnymi.

Słowa klucze: sprostowania; błędy thumaczeniowe; korekty przekładu; zapewnienie jakości przekładu; przekład instytucjonalny; organizacje międzynarodowe; instytucje Unii Europejskiej; pewność prawa.

\section{The significance of corrigenda in institutional translation studies}

As noted by Byrne (2007: 3), "[t]he sheer volume and diversity of translation work which takes place throughout the world each year means that there are potentially dozens, if not hundreds, of possible implications" of faulty translations. He illustrates the "real and potential" consequences of "inappropriate, incorrect, ambiguous or otherwise defective translations" (Byrne 2007: 2) with examples of errors in translations of legal, political and commercial texts. He provides a list of EU directives that establish requirements for accurate and clear translations of technical documentation in order to address the problem of "faulty translations" of operating instructions raised by Council Resolution 98/C 411/01 of 17 December 1998 on operating instructions for technical consumer goods. One of the examples of errors examined is drawn from the German translation of an EU directive itself (Byrne 2007: 6). In a study conducted for the European Commission's Directorate-General for Translation (DGT) a few years later, further examples of errors detected in specific language versions of several EU regulations were analyzed to illustrate their potential legal consequences, including changes in product labelling or in the scope of certain provisions (European Commission 2010: 148-149).

Considering the high volume of translations they produce, it is no surprise that institutional language services are particularly exposed to undetected mistakes, as no workflow can guarantee infallible (i.e. error-free) multilingual text production (see e.g. Drugan 2013). While quality assurance measures taken by these professional services significantly reduce the risk of errors, as a general rule, factors such as time pressure and insufficient quality control (increasingly associated with outsourcing of documents and over-reliance on machine 
translation) can contribute to translation issues being overlooked in the process. It is no coincidence either that the higher exposure of the EU institutions, owing to their increasing number of official languages and the direct applicability of their legislation (see e.g. Strandvik 2018), has prompted earlier and more explicit actions on the matter than in other institutional contexts. As acknowledged in the Empowerment to correct errors, including minor errors, in translations of acts adopted by the Commission in 2008 (SEC(2008) 2397), immediately after the major EU enlargements of 2004 and 2007, "[t]he increase in the number of language versions of the texts adopted by the Commission" (from 10 in 1995 to 20 in 2004 and 23 in 2007) "has also led to an increase in the risk of translation errors. Consequently, there has been an increase in the number of corrections of translation errors adopted by the Commission" (European Commission 2008: 3) and, therefore, an increase in the number of corrigenda issued to this end. Soon after, in its study Quantifying Quality Costs and the Cost of Poor Quality in Translation, the DGT highlighted not only the financial implications of translation errors for the EU due to the cost of processing corrigenda (and even dealing with court cases), but also the potential impact on the reputation of the EU institutions, and the serious risks in terms of legal certainty, including for citizens and companies (European Commission 2012). This latter question is especially delicate in the case of meaningchanging corrigenda of legislative texts with retroactive effects (on the legal implications, see Bobek 2009, 2011).

These concerns also apply to other institutional translation services, and are particularly serious when dealing with binding instruments or sensitive policy documents. Given the implications for translation quality and professional reputation, the attention devoted so far to corrigenda in Translation Studies seems clearly insufficient. Yet, in a field in which quality is, above all, associated with the lack of errors, the analysis of mistakes and corrections emerges as a key aspect of both assessment and competence development. In the area of institutional translation, and in international organizations in particular, error analysis is not only essential for professional development as a translator, but also for systemic processes of quality control, monitoring, appraisal and training.

This study will shed light on what corrigenda reveal about the most common errors detected and corrected in institutional translations over a recent decade: between 2005 and 2015. It draws on the 
LETRINT corpora, ${ }^{1}$ which cover all multilingual text production in English, French and Spanish over this period in three settings: the European Union (EU), the United Nations (UN) and the World Trade Organization (WTO). After a review of the procedures used to introduce corrections in these settings (Section 2), more details on corpus and methodology will be provided (Section 3) before presenting the results of the quantitative and qualitative analysis of translationtriggered corrigenda in two target languages, French and Spanish, according to various parameters: setting, year, genre, error type and severity (Section 4). Finally, the implications of our findings from the perspective of translation quality assurance will be discussed in the conclusions (Section 5).

\section{How do institutional translation services deal with corrigenda?}

In order to contextualize our analysis, we will briefly examine how international organizations deal with translation errors after the adoption and publication of official documents. The correction of international legal instruments in general is governed by Article 79 of the 1969 Vienna Convention on the Law of Treaties (VCLT), which establishes that:

1. Where, after the authentication of the text of a treaty, the signatory States and the contracting States are agreed that it contains an error, the error shall, unless they decide upon some other means of correction, be corrected:

(a) by having the appropriate correction made in the text and causing the correction to be initialled by duly authorized representatives; (b) by executing or exchanging an instrument or instruments setting out the correction which it has been agreed to make; or (c) by executing a corrected text of the whole treaty by the same procedure as in the case of the original text.

\footnotetext{
${ }^{1}$ These corpora have been built as part of the project "Legal Translation in International Institutional Settings: Scope, Strategies and Quality Markers" (LETRINT), led by the author and supported by the Swiss National Science Foundation through a Consolidator Grant.
} 


\section{Fernando Prieto Ramos: Facing Translation Errors...}

According to para. 3 of the same Article, the above also applies "where the text has been authenticated in two or more languages and it appears that there is a lack of concordance which the signatory States and the contracting States agree should be corrected." In practice, the most common way to correct errors introduced during the translation process is through corrigenda.

Based on a comparative analysis of the internal guidelines on the issuance of corrigenda and consultation with institutional informants, several commonalities and differences have been identified between the contexts examined. The way corrections are handled may vary depending on how serious the error is, and on whether it is found in the original version or the other language versions. For instance, in the case of European Commission's legal acts, the Secretary-General deals with corrections in the first case, ${ }^{2}$ while the DGT processes requests in the latter case through its dedicated Corrigenda Team, in cooperation with the Legal Service and the directorates-general (DGs) who authored the document (European Commission 2012: 29-30). This is possible since 2008 under the above-mentioned Empowerment Decision SEC(2008) 2397, ${ }^{3}$ which establishes three cumulative conditions:

\footnotetext{
- the error concerns only one or more language versions other than the original version;

- the error is easily recognisable in the text concerned or is found beyond doubt to be serious when a comparison is made with the version in the original language;

- the error is caused by the mistranslation or omission of one or more elements of the text without, however, affecting the substance of the text as a whole. In particular, errors affecting the overall conclusion of the act (e.g. state aid "is" instead of "is not" authorised) and errors
}

\footnotetext{
${ }^{2}$ By a decision of 1977 (SEC(1977) 2532/1, PV(1977) 438), the Commission delegated to the Secretary-General the adoption of corrections of "obvious errors", understood as "easily recognisable in the text (for example, spelling mistake, typing error, printing error, an error in a calculation, missing text, meaningless text)" (cited in European Commission 2008: 3). This definition of "obvious errors" is maintained in the recent decision of 2017 (C(2017) 4898 final): "easily recognisable errors in the text (e.g. spelling, typing or printing errors, mathematical errors or the omission of one or more words or of part of the text)" (Commission Decision of 12.7.2017 on delegation of the power to correct obvious errors in Commission acts, p. 2).

${ }^{3}$ Completed by Commission Decision subdelegating the power to correct errors, including minor omissions, in translated versions of acts adopted by the Commission (C(2010) 3031), from the Member of the Commission responsible for Education, Culture, Multilingualism and Youth to the DGT.
} 
relating to a key word in the act which are repeated throughout the text are excluded from this empowerment (European Commission 2008: 3).

The distinction between "easily recognisable" or "serious" errors, on the one hand, and mistranslations or omissions "affecting the substance of the text", on the other, is most relevant. If the Legal Service finds an error to be substantial, a correcting act must be prepared and adopted through "a procedure similar to that followed for the adoption of a text containing errors" (European Commission 2008: 3), whether these affect the original or other language versions.

In the EU Council and the European Parliament, all corrections of legal acts published in the Official Journal are handled by their lawyer-linguists (from the Council's Directorate for the Quality Legislation and the Parliament's Directorate for Legislative Acts). The rectification process is governed by Council document R/2521/75 (JUR 149) of 1975 , which is largely inspired by the VCLT principles. In this process, only non-obvious errors may require the adoption of a new act rather than a corrigendum after consultations with the relevant EU and national authorities. With regard to this process, the "Procedure for Adopting Corrigenda" set out in the Manual of precedents for acts established within the Council of the European Union specifies that a corrigendum "is made to those parts of the text that are so lacking in form as to be incomprehensible, as well as to errors liable to produce undesired legal effects (obvious typing or language errors that are unimportant should not be corrected by a corrigendum)" (Council of the EU 2015: 176). In the case of acts adopted under the ordinary legislative procedure (previously, co-decision procedure), draft corrigenda must obtain the agreement of the European Parliament, which handles corrections in accordance with Rule 231 of the institution's Rules of Procedure.

At the Court of Justice of the EU (CJEU), rectification orders are issued if the error is found in the authentic language of the case. If it is detected in another language version, the correction can be introduced in a footnote that refers to the modified paragraphs. In this judicial context, however, what attracts more attention is how divergences between different language versions of legal acts surface in Court cases and call for multilingual interpretation of EU law (see e.g. Dengler 2010, Baaij 2012, Prieto Ramos and Pacho Aljanati 2018). Indeed, this subject is beyond the scope of our study and deserves separate investigation. 
In the United Nations Editorial Manual Online, a distinction is made between corrigenda and reissues. The second category, "reissue for technical reasons", was formally recognized as a text category on 16 March 2010 under a revised section "Corrigenda and reissues", although it had been practiced since long before (examples are already found as early as the late 1970s). In the 1983 United Nations Editorial Manual, a "corrigendum" was defined as "a document issued to correct an error or errors in the text of an existing document or publication (that is, one that has been distributed), whether for substantive or for technical reasons" (United Nations 1983: 145). Reissues for technical reasons were not listed as "special types of texts" together with "corrigenda and errata" (headings of the 1983 Manual), but they were addressed in a less prominent position as part of an introductory chapter on "document symbols", as follows:

\begin{abstract}
On the rare occasions when it is deemed necessary to reissue a document in its entirety because of a technical error such as serious misprints or errors resulting from the malfunctioning of a machine, complete texts of corrected documents may be issued under the original symbol followed by an asterisk and a corresponding footnote reading "Reissued for technical reasons". The symbol element "Rev." is not used in such cases since it might seem to imply a substantive change in the document. (United Nations 1983: 14)
\end{abstract}

In principle, neither corrigenda (currently defined as documents "issued to correct an error or errors in a document or publication that has already been issued", without the previous reference to substantive or technical reasons) nor "reissues for technical reasons" are used "merely to correct minor typographical errors". ${ }^{5}$ Both categories are issued only in the languages to which corrections apply, but only corrigenda are published as separate documents (i.e. with their own symbol) specifically to explain the corrections. In documents reissued for technical reasons, an asterisk is added to the original symbol and a footnote is inserted to indicate that the new version is motivated by technical reasons ("Reissued for technical reasons on [date]"), without specifying them, except for "reissues to correct a symbol" or to "change to a dual symbol", where a second sentence is added to the general formula: "[...]; previously issued under the symbol [original

\footnotetext{
${ }^{4}$ See list of updates at: http://www.dgacm.org/editorialmanual/list_updates.htm.

${ }^{5} \mathrm{http} / / /$ www.dgacm.org/editorialmanual/ed-guidelines/types_documents/corrigenda.htm.

This has applied to corrigenda since before (see United Nations 1983: 145).
} 
symbol]". ${ }^{6}$ However, the asterisk is excluded from subsequent references to the document, and the original version is withdrawn and replaced by the corrected version, which means that the exact nature of the changes is untraceable unless the specific reasons for the reissue are further investigated. As confirmed by UN informants, in compliance with the current Editorial Manual, errors introduced during the translation process qualify as a "technical reason" for reissue of a document, together with editing and text processing errors, as opposed to substantive errors by the submitting office, which should normally be corrected through corrigenda. Even if, according to the same sources, the distinction is not always clear-cut and strictly followed in practice, the scope and prominence of reissues for technical reasons have evolved since 1983, when these were reserved for rare cases of serious misprints or machine malfunctioning, and other "technical reasons" not considered "substantive" were also tackled through corrigenda. To illustrate recent translation-triggered "reissues for technical reasons", the following corrections were detected through the comparison of the original version (retrieved from cached webpages) and the reissued versions:

Example 1 (EN): “(c) They are not marked in accordance with the provisions of this instrument; $[\ldots]$ "

Initial FR: “c) Elles sont marquées conformément aux dispositions du présent instrument; [...]"

Reissued FR: “c) Elles ne sont pas marquées conformément aux dispositions du présent instrument; [...]" (emphasis added)

(UN working group report A/60/88 of 2005)

Example 2 (EN): “[...] if a Member State determines that a DPRK diplomat, governmental representative, or other DPRK national acting in a governmental capacity, is working on behalf or at the direction of a designated individual or entity, or of an individual or entities assisting in the evasion of sanctions or violating the provisions of resolutions [...]."

Initial ES: “[...] si un Estado Miembro determina que un diplomático, representante gubernamental $u$ otro nacional de la RPDC que se desempeñe en carácter oficial está actuando en nombre o bajo la dirección de una persona o entidad designada, facilitando la evasión de sanciones o contraviniendo las disposiciones de las resoluciones [...]."

\footnotetext{
${ }^{6} \mathrm{http}: / / \mathrm{www} . d g a c m . o r g /$ ditorialmanual/ed-guidelines/types_documents/corrigenda.htm.
} 
Reissued ES: “[...] si un Estado Miembro determina que un diplomático, representante gubernamental u otro nacional de la RPDC que se desempeñe en carácter oficial está actuando en nombre o bajo la dirección de una persona o entidad designada, $\underline{\text { o de una persona }}$ o entidad que facilite la evasión de sanciones o contravenga las disposiciones de las resoluciones [...]." (emphasis added)

(UN Security Council Resolution 2270 of 2016)

In the case of the WTO, corrigenda are issued "when the corrections to be made to the original document, whether substantive or non-substantive, can be explained easily" (internal note Revision, Corrigendum, Addendum, Supplement-Meaning and Use). They are circulated in any or all of the Organization's three official languages.

Despite the relevance of severity in dealing with corrections at all the above institutions, the criteria to assess and classify mistakes are not always explicit or shared between legal and language services. Nonetheless, in the case of translations, as reflected in Empowerment Decision SEC(2008) 2397, it is presupposed that the greater the deviation is from the intended meaning of the original text, the more substantial and serious the potential impact, especially when binding texts are affected. At the other extreme, minor typographical errors, as specified in the UN editorial guidelines, might not be enough to publish a correction.

\section{Corpus and methodology}

Our analysis will concentrate on corrections of translation-triggered issues, i.e. explicit corrections of errors or omissions that were introduced during the translation process, and were detected after publication and deemed relevant to issue corrigenda, regardless of the more or less substantial impact on the meaning. As the main purpose of the study is to quantify and classify these issues with a view to identifying and discussing potential patterns in error types, our corpus is composed of all corrigenda published in French or Spanish as target languages in the three institutional settings of the study in 2005, 2010 and 2015. As mentioned above, they were extracted from the LETRINT corpora. In the case of the EU, the source selected is EUR-Lex, not only because it is the main database of EU legal texts, including the 
translations of the three institutions involved in the ordinary legislative procedure (the European Commission, the Council of the EU and the European Parliament), but also because a preliminary test with corrigenda retrieved from the other repositories used in the LETRINT project (the European Council Document Register, the European Parliament Public Register of Documents and the Register of Commission Documents) yielded few additional data, and these often referred to preparatory documents (cover notes, proposals, agendas, etc.). As to the UN and the WTO, the main source repositories consulted are the UN's Official Document System (ODS) and the WTO Documents Online, respectively.

The three translation languages selected are those common to all the settings analyzed. They are considered in their most frequent directionality, i.e. translation of English language original texts into French and Spanish. For this reason, among others, documents from the International Court of Justice (ICJ) and the CJEU were not included in this study. In the latter institution, the use of French as procedural language and the variation of formats used to introduce corrections (rectification orders and footnotes) would have required a separate study.

From a diachronic perspective, the period examined is of major relevance to observe changes in translation correction trends and their potential connection with technology advances, quality assurance measures and other institution-specific developments. For example, in the case of the EU, the first year of the corpus (2005) is the one following the massive EU enlargement of 2004, while the second year (2010) comes after the 2007 enlargement and the 2008 empowerment of the DGT for processing certain corrigenda. At the UN, 2010 also saw the more formal recognition of reissues for technical reasons as a text category in its Editorial Manual. Since the error types that originate these documents are not fully traceable because their original versions are unavailable after being replaced, as mentioned above, they were excluded from the quantitative analysis of corrections. However, the official formulation reproduced in the footnotes of these corrected versions made it possible to retrieve all reissues for technical reasons of 2005, 2010 and 2015 (see Table 3 in Section 4.1). Despite the lack of precise information on the motivations for these reissues, they must be considered when reviewing quantitative findings on UN corrigenda. 
The following metadata were registered and analyzed: setting, year, target language, error type, genre and degree of severity. Whereas the more general data could be extracted from the LETRINT corpora, error types had to be defined for the categorization of corrections. An initial list of common error types in translation assessment was gradually refined through the analysis of the corrigenda compiled. The final list includes two groups of error types from the perspective of translation decision-making:

(1) Content reformulation corrections associated with mistranslations or incomplete translations, normally perceived as serious translation errors:

- unjustified omission

- unjustified addition

- opposite meaning

- incorrect terminology

- incorrect meaning or inaccuracy (not included above)

(2) Minor formal corrections of errors mostly associated with details overlooked in the translation process:

- reference (e.g. legislation or provision number)

- proper name (e.g. body, person, programme, acronym)

- figure

- date

- concordance or cohesion issue (e.g. number and gender agreement, word repetition)

- $\quad$ spelling or typographical error ${ }^{7}$

This distinction cannot be entirely correlated with specific levels of severity or risk, as the second group of errors may also have serious consequences (e.g. a wrong figure or a spelling mistake that may change the meaning significantly) (see Section 4.4). Yet, this group can

\footnotetext{
${ }^{7}$ The risk of some minor errors being occasionally introduced in the typesetting process of certain texts, i.e. re-typing or printing errors not caused by translators or revisers, albeit extremely rare, would need to be considered as a factor for errors introduced until the early 2000s in particular. However, according to our analysis of workflows, corpus components and feedback from institutional informants, this factor would not affect our assumptions regarding translation-triggered spelling or typographical errors for the 2005-2015 period under examination. Very few texts from previous decades were subject to corrigenda issued in this period, and the potential impact of typesetting errors in this study would thus be too insignificant to attempt to isolate them through further research.
} 
be more clearly linked to lack of attention to detail, as opposed to a stronger connection of the first group of errors with inappropriate research, analysis and reformulation decision-making in the translation process. The above classification is only partially similar to Bobek's legal distinction with regard to EU legislative corrigenda. $\mathrm{He}$ distinguishes between: (a) "purely formal corrigenda" or "genuine corrigenda" that "rectify typographic mistakes and omissions, obvious flaws in writing or type-setting", e.g. "omitted letters, small instead of capital letters at the beginning of a sentence, incorrect internal references caused by a typing mistake, wrongly type-set sentences or paragraphs, and so on"; and (b) "meaning-changing corrigenda [...] that substantively alter the content of the legal norm", e.g. "narrowing or broadening of notions in a legal text, changing the nature of a list of conditions to be fulfilled (from enumerative to exhaustive), turning positive sentences into negative ones, or even plainly rewriting of substantive parts of a piece of EC legislation" (Bobek 2009: 951). In practice, however, based on the guidelines reviewed in Section 2, we can expect most corrections leading to corrigenda, except for minor typographical errors (which often do not suffice to motivate a corrigendum), to have some degree of semantic impact (see Section 4.4).

Our specific error categories align, to a large extent, to those used for evaluation purposes at the DGT (which, in turn, are more elaborate than the taxonomies used at other organizations ${ }^{8}$ ): mistranslation; unjustified addition; unjustified omission or nontranslation; reference documents / material not used; norm sources or job-specific instructions not adhered to; wrong or inconsistent EU usage or terminology; clarity, register and text-type conventions; punctuation; grammar (Strandvik 2017: 126). Our corpus yielded more nuance in the case of formal correction categories, as well as "opposite meaning" as a specific type of semantic distortion, whereas three DGT categories (job-specific instructions, reference documents and clarity or text-type conventions) did not seem to lead to corrigenda or may be associated with other errors such as incorrect terminology (as a result of inconsistent use of reference material or non-adherence to conventions).

As in the case of the WTO (for the entire period covered), the DGT shared its data of registered corrigenda for 2010 and 2015, but without any classification of errors. Nonetheless, these data were

\footnotetext{
${ }^{8}$ As per internal forms consulted.
} 
very useful for verifying the overall coherence of the trends elicited by our own results.

As in any categorization work, the risk of overlap and borderline cases emerged as a challenge. For instance, in a corrigendum to Commission Regulation (EU) No 316/2014 in Spanish, the correction of "licenciante" in lieu of "licenciatario" (for the English original "licensor") in Article 1(1), point (p), could qualify as opposite meaning. However, whenever a terminological issue was the origin of a semantic deviation, this more specific error type prevailed for categorization. Further examples of error types will be provided in Section 4.

\section{Findings on correction patterns}

The results of our combined quantitative and qualitative analyses will be presented from more general to more specific. An overview of the number of corrigenda and corrections will be followed by the breakdown of the main genres where they were found, the error types and their degrees of severity.

\subsection{Overall number of corrigenda and corrections}

Corrections were discriminated by translation directionality in order to exclude original drafting problems and concentrate exclusively on errors introduced in the translation process. For the sake of consistency and comparability in the quantitative analysis, errors were counted using corrected sentence-level segments as units, regardless of how corrections are presented in each corrigendum. This is particularly relevant in the case of segments where more than one lexical unit is modified to correct a single mistranslation. By the same token, when a term or formulation is harmonized in several segments, the error corrected is counted only once, as a single translation decision. 
Table 1. Number of corrigenda ordered by number of corrected segments per document

\begin{tabular}{|c|c|c|c|c|c|c|c|c|c|c|c|c|c|c|c|c|c|c|c|c|c|c|}
\hline \multirow{3}{*}{$\begin{array}{l}\text { Corrected } \\
\text { segments } \\
\text { (per doc) }\end{array}$} & \multicolumn{7}{|c|}{2005 corrigenda } & \multicolumn{7}{|c|}{2010 corrigenda } & \multicolumn{7}{|c|}{2015 corrigenda } & \\
\hline & \multicolumn{2}{|c|}{$\mathrm{EU}$} & \multicolumn{2}{|c|}{ UN } & \multicolumn{2}{|c|}{ WTO } & \multirow[b]{2}{*}{$\begin{array}{l}\text { Sub- } \\
\text { total }\end{array}$} & \multicolumn{2}{|c|}{$\mathrm{EU}$} & \multicolumn{2}{|c|}{ UN } & \multicolumn{2}{|c|}{ WTO } & \multirow[b]{2}{*}{$\begin{array}{l}\text { Sub- } \\
\text { total }\end{array}$} & \multicolumn{2}{|c|}{$\mathrm{EU}$} & \multicolumn{2}{|c|}{ UN } & \multicolumn{2}{|c|}{ WTO } & \multirow[b]{2}{*}{$\begin{array}{l}\text { Sub- } \\
\text { total }\end{array}$} & \multirow[b]{2}{*}{ Total } \\
\hline & ES & FR & ES & FR & ES & FR & & ES & FR & ES & FR & ES & FR & & ES & FR & ES & FR & ES & FR & & \\
\hline 1 & 15 & 18 & & 15 & 3 & 4 & 55 & 30 & 33 & 4 & 8 & 3 & 3 & 81 & 66 & 51 & & 1 & 1 & 2 & 121 & 257 \\
\hline 2 & & 2 & & 2 & & & 4 & 1 & 5 & & 1 & & & 7 & 6 & 6 & & & & & 12 & 23 \\
\hline 3 & 1 & & & & & 1 & 2 & 3 & 2 & & & & & 5 & 3 & 1 & & 1 & & & 5 & 12 \\
\hline 4 & & 1 & & 2 & & & 3 & & 1 & & & & & 1 & 1 & 1 & & & & & 2 & 6 \\
\hline 5 & & 1 & 1 & & & & 2 & & & 1 & & & & 1 & 1 & 1 & & & & & 2 & 5 \\
\hline $6-10$ & 2 & 2 & & 2 & & & 6 & 3 & 2 & & 1 & & & 6 & 4 & 2 & & & 2 & & 8 & 20 \\
\hline $11-65$ & & & & 1 & & & 2 & 7 & 2 & & & & & 9 & 4 & 3 & 2 & 2 & & 1 & 12 & 22 \\
\hline Total & 18 & 24 & 1 & 22 & 3 & 5 & 73 & 44 & 45 & 5 & 10 & 3 & 3 & 110 & 85 & 65 & 2 & 4 & 3 & 3 & 162 & 345 \\
\hline
\end{tabular}

Figure 1. Distribution of groups of corrigenda per number of corrected segments

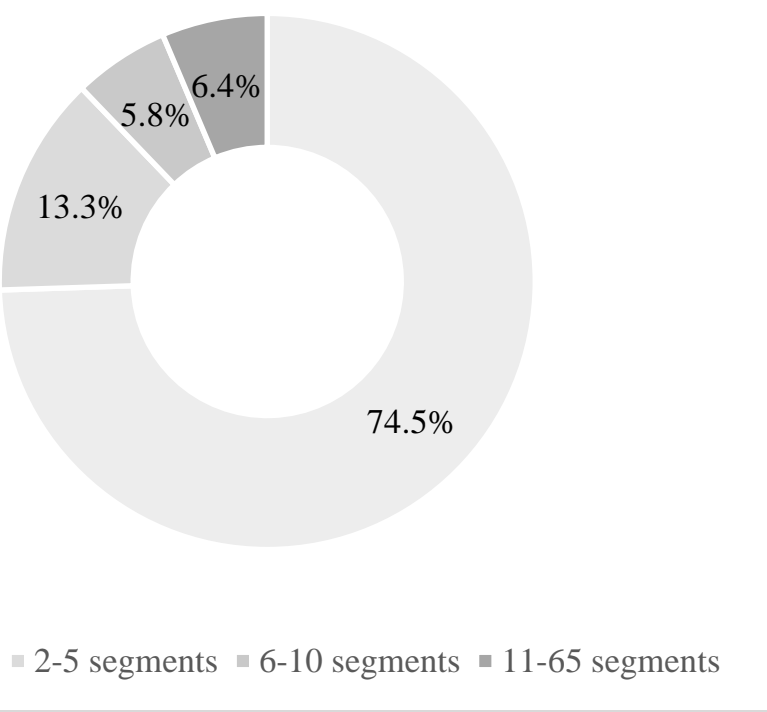

1 segment $₫ 2-5$ segments $₫ 6-10$ segments $\approx 11-65$ segments

The first results (Table 1 and Figure 1) show that an overwhelming majority of corrigenda contain a single correction (almost 75\%), and that the number of corrigenda decrease as the number of errors per text increase: $13.33 \%$ of corrigenda include 2 to 5 corrections, $5.8 \%$ contain 6 to 10 corrections, and $6.38 \%$ include between 11 and 65 . This last figure was the maximum number of translation-triggered errors corrected in a single corrigendum. Three 
other EU documents (one from 2010 and two from 2015) were excluded from the calculations because they contained a disproportionate number of corrections and it soon became apparent that these corrigenda were issued to replace document versions initially published by mistake. These cases would not qualify as corrections of translation decisions, but as changes derived from mistakes in the processing of documents. Their inclusion would have distorted the analysis of translation error patterns.

Table 2. Number of corrigenda and corrections (corrected segments)

\begin{tabular}{|c|c|c|c|c|c|c|c|c|c|c|c|c|c|c|c|c|c|c|c|c|c|c|c|c|c|c|}
\hline \multirow{3}{*}{$\begin{array}{c}\text { Docs (D) } \\
\& \text { corrected } \\
\text { segments (C) }\end{array}$} & \multicolumn{6}{|c|}{2005} & & & \multicolumn{6}{|c|}{2010} & & & \multicolumn{6}{|c|}{2015} & & & \multicolumn{2}{|c|}{ Total } \\
\hline & \multicolumn{2}{|c|}{$\mathrm{EU}$} & \multicolumn{2}{|c|}{ UN } & \multicolumn{2}{|c|}{ WTO } & & & \multicolumn{2}{|c|}{$\mathrm{EU}$} & \multicolumn{2}{|c|}{ UN } & \multicolumn{2}{|c|}{ WTO } & & & \multicolumn{2}{|c|}{$\mathrm{EU}$} & \multicolumn{2}{|c|}{ UN } & \multicolumn{2}{|c|}{ WTO } & & & & \\
\hline & \#D & $\# \mathrm{C}$ & $\# \mathrm{D}$ & $\# \mathrm{C}$ & $\# \mathrm{D}$ & $\# \mathrm{C}$ & $\# \mathrm{D}$ & $\# \mathrm{C}$ & \#D & $\# \mathrm{C}$ & \#D & $\# \mathrm{C}$ & $\# \mathrm{D}$ & $\# \mathrm{C}$ & $\# \mathrm{D}$ & $\# \mathrm{C}$ & $\# \mathrm{D}$ & $\# \mathrm{C}$ & \#D & $\# \mathrm{C}$ & $\# \mathrm{D}$ & $\# \mathrm{C}$ & $\# \mathrm{D}$ & $\# \mathrm{C}$ & \#D & $\# \mathrm{C}$ \\
\hline ES & 18 & 36 & 1 & 5 & 3 & 3 & 22 & 44 & 44 & 200 & 5 & 9 & 3 & 3 & 52 & 212 & 85 & 221 & 2 & 74 & 3 & 13 & 90 & 309 & 164 & 565 \\
\hline FR & 24 & 48 & 22 & 90 & 5 & 7 & 51 & 145 & 45 & 99 & 10 & 19 & 3 & 3 & 58 & 121 & 65 & 263 & 4 & 48 & 3 & 28 & 72 & 339 & 181 & 606 \\
\hline Total & 42 & 84 & 23 & 95 & 8 & 10 & 73 & 189 & 89 & 299 & 15 & 28 & 6 & 6 & 110 & 333 & 150 . & 484 & 6 & 122 & 6 & $4 \mathrm{I}$ & 162 & 647 & 345 & 1170 \\
\hline
\end{tabular}

Figure 2. Changes in number of corrigenda in each setting

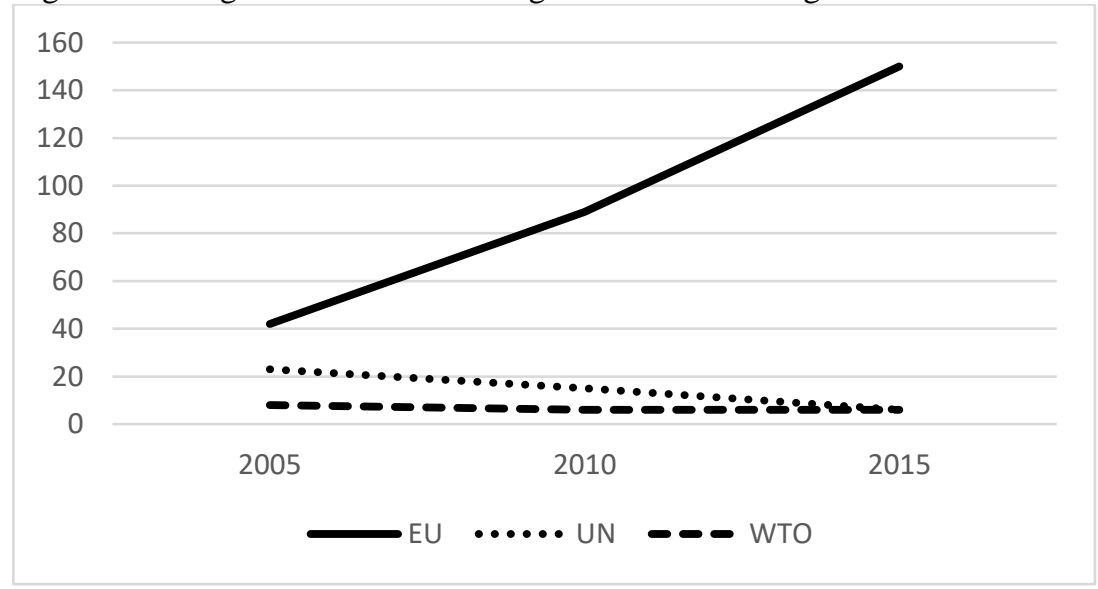

Table 3. Reissues for technical reasons at the UN

\begin{tabular}{|l|c|c|c|c|}
\hline Language of reissue & 2005 & 2010 & 2015 & Total \\
\hline FR & 18 & 49 & 92 & 159 \\
\hline ES & 7 & 8 & 31 & 46 \\
\hline ES \& FR & 5 & 11 & 32 & 48 \\
\hline Total & 30 & 68 & 155 & 253 \\
\hline
\end{tabular}


The statistics also confirm clear trends in each institutional setting (see Table 2 and Figure 2). In the EU, there is a marked increase of both corrigenda and corrections, from a total of 42 corrigenda and 84 corrected segments in 2005 to 150 and 484, respectively, in 2015. This trend is comparable for both target languages, even if the ratio of corrected segments per corrigendum may vary per year. This means that fewer corrigenda in one language may correct more segments in total than corrigenda in the other target language in a particular year (e.g. the case of Spanish in 2010 and French in 2015). At the WTO, figures are very low and stable, with between 6 and 8 corrigenda per year, evenly distributed per language. In contrast, the UN registered a remarkable downward trend, from 23 corrigenda in 2005 to 6 in 2015, including a systematically higher proportion of corrigenda in French. This is partly explained by the fact that some corrections were found in documents that are translated into French but not into Spanish, including 13 corrigenda of texts on technical regulations issued by the United Nations Economic Commission for Europe (UNECE) (7 in 2005 and 5 in 2010).

Coincidentally, in both the WTO and the UN, there was a peak in the number of corrected segments per document in 2015, but no trend can be inferred from these data. Furthermore, in the case of the UN, as noted in Section 3, the number of corrigenda must be read in conjunction with the number of reissues for technical reasons. In fact, recourse to this procedure grew exponentially over the period examined (see Table 3). Reissues for technical reasons available only in French and/or Spanish (none of them produced to correct symbols or to change dual symbols) more than doubled every five years, from a total of 30 in 2005 to 68 in 2010 and 155 in 2015 . While the number of translationrelated errors corrected (and their translation directionality) cannot be determined within this group of documents, it can be assumed that a proportion of their growing number was triggered by translation issues.

The above quantitative findings are not meant to be exhaustive but rather indicative of overall trends. They are a first step to further investigating the nature and potential impact of corrigenda from a more qualitative angle. For a more nuanced analysis of quantitative patterns as an indicator of error frequency and quality control effectiveness, the data must be examined in the light of total translation volumes and other extra-textual factors. 


\subsection{Correction density per genre}

As previously argued, the main aim of the quantitative analysis is not to calculate precise indexes of translation error incidence in each institution, something that language services are better positioned to monitor. In the case of the DGT, a "correction rate" is used as one of the "result indicators" about the objective of "delivering high quality translation and editing services" (DGT 2016: 9). ${ }^{9}$ In this comparative study, given the significant differences in translation volumes between institutions, an effective and highly reliable way of addressing the question of error incidence was by examining the density of corrigenda and corrections per translation volume of the affected genres. Two ratios were calculated:

(1) ratio of corrigenda to textual units (ratio 1), i.e. the average number of corrigenda per target language and total number of original texts of the genre examined; and

(2) ratio of corrections to translation volumes (ratio 2), i.e. the average number of corrections (as per corrected segments) made per target language and million words of original text of the genre in question.

By adding the total volume of words as reference point (and not only the number of documents, as in the case of the DGT's correction rate), a more balanced account of the density of corrigenda could be described considering the level of exposure to errors (i.e. the larger the volume of text translated, the higher the risk of overlooking mistakes). For example, in the case of WTO dispute settlement panel reports, only one corrigendum was issued for the 31 texts of the genre in the three years of the corpus, resulting in a higher ratio $1(1.61 \%)$ than the genre that registered the largest number of corrigenda, notifications by Members States, with 4 corrigenda in a total of 7320 documents (or a ratio 1 of $0.03 \%$ ). However, the total translation volumes of these two genres $(5.92 \mathrm{~m}$ versus $5.32 \mathrm{~m}$, respectively) are not as divergent as their numbers of texts (31 versus 7320), which means that the panel reports'

\footnotetext{
9 This "correction rate" is defined as the "ratio between the number of translations formally corrected during one year and the number of translations of the same year and the preceding two years that can be subject to such corrections"; and the target for 20162020 is to keep it under 0.5\% (DGT 2016: 9).
} 
ratio $2(0.08$ corrections per target language and million words of original text) is almost five times lower (and impressively low by all standards) than that of notifications (ratio 2 of 0.38 corrections per million words). All other WTO corrigenda in our corpus apply to genres with less than one million words of original text volume, and do not exceed two corrigenda per genre.

Table 4. Corrigenda and correction density ratios of UN genres with high translation volumes

\begin{tabular}{|l|r|r|r|r|r|r|}
\hline \multirow{2}{*}{} & \multicolumn{2}{|c|}{$\begin{array}{c}\text { TRANSLATION } \\
\text { VOLUME } \\
\text { (ORIGINAL TEXT) }\end{array}$} & \multicolumn{4}{|c|}{ CORRIGENDA } \\
\cline { 2 - 7 } & \multicolumn{1}{|l|}{ \#D } & Total words & \#D & \#C & Ratio 1 & Ratio 2 \\
\hline UN body report & 714 & $8,049,047$ & 9 & 113 & $0.63 \%$ & 7.02 \\
\hline Special rapporteur report & 199 & $2,049,287$ & 2 & 10 & $0.50 \%$ & 2.44 \\
\hline Agenda & 1,347 & $1,448,801$ & 2 & 6 & $0.07 \%$ & 2.07 \\
\hline Activity report & 227 & $1,364,125$ & 1 & 1 & $0.22 \%$ & 0.37 \\
\hline Financial report & 110 & $1,628,530$ & 1 & 1 & $0.45 \%$ & 0.31 \\
\hline Budget & 366 & $4,075,111$ & 2 & 2 & $0.27 \%$ & 0.25 \\
\hline Report of the Secretary-General & 1,214 & $9,008,674$ & 2 & 3 & $0.08 \%$ & 0.17 \\
\hline
\end{tabular}

Table 5. Genres of UN reissues for technical reasons (excluding genres with less than 10 reissues)

\begin{tabular}{|l|r|r|r|r|}
\hline & 2005 & 2010 & 2015 & \multicolumn{1}{c|}{ Total } \\
\hline Resolution & 4 & 22 & 23 & 49 \\
\hline Report of the Secretary-General & 3 & 8 & 16 & 27 \\
\hline Budget & - & 7 & 13 & 20 \\
\hline Agenda & 2 & 2 & 12 & 16 \\
\hline Letter & 4 & 4 & 6 & 14 \\
\hline General Assembly committee report & 3 & - & 7 & 10 \\
\hline Country programme & - & - & 10 & 10 \\
\hline
\end{tabular}

In the case of UN genres, error incidence could only be analyzed in an approximate way, by calculating their corresponding ratios and verifying the genres affected by reissues for technical reasons as a very general indication (see Section 2). Table 4 shows that all genres with more than 100 texts and one million words of translation 
volume present very low numbers of corrigenda. ${ }^{10}$ Various types of reports are the most represented genres, while resolutions are, by far, the most frequently reissued for technical reasons (49 reissues over the three years of the corpus, followed by 27 reissues of reports of the Secretary-General) (see Table 5).

Table 6. Corrigenda and correction density ratios of EU genres with high translation volumes

\begin{tabular}{|l|r|r|r|r|r|r|}
\hline \multirow{2}{*}{} & \multicolumn{2}{|c|}{$\begin{array}{c}\text { TRANSLATION } \\
\text { VOLUME }\end{array}$} & \multicolumn{4}{|c|}{ CORRIGENDA } \\
\cline { 2 - 7 } & \#D & $\begin{array}{c}\text { Total } \\
\text { words }\end{array}$ & \#D & \#C & Ratio 1 & Ratio 2 \\
\hline Regulation & 3,708 & $6,965,847$ & 156 & 587 & $2.10 \%$ & 42.13 \\
\hline Commission Regulation & 3,410 & $5,348,620$ & 105 & 474 & $1.54 \%$ & 44.31 \\
\hline Council Regulation & 213 & $1,030,885$ & 22 & 50 & $5.16 \%$ & 24.25 \\
\hline $\begin{array}{l}\text { Regulation of the European } \\
\text { Parliament and of the Council }\end{array}$ & 85 & 586,342 & 29 & 63 & $17.06 \%$ & 53.72 \\
\hline Decision & 2,031 & $4,560,837$ & 33 & 38 & $0.81 \%$ & 4.17 \\
\hline Commission Decision & 1,107 & $3,391,274$ & 18 & 19 & $0.81 \%$ & 2.80 \\
\hline Decision of the European Council & 849 & $1,087,614$ & 14 & 18 & $0.82 \%$ & 8.27 \\
\hline $\begin{array}{l}\text { Decision of the European } \\
\text { Parliament and of the Council }\end{array}$ & 75 & 81,949 & 1 & 1 & $0.67 \%$ & 6.10 \\
\hline Directive & 208 & $1,200,722$ & 50 & 106 & $12.02 \%$ & 44.14 \\
\hline Council Directive & 22 & 111,379 & 9 & 13 & $20.45 \%$ & 58.36 \\
\hline $\begin{array}{l}\text { Directive of the European } \\
\text { Parliament and of the Council }\end{array}$ & 52 & 588,739 & 37 & 77 & $35.58 \%$ & 65.39 \\
\hline Commission Directive & 134 & 500,604 & 4 & 16 & $1.49 \%$ & 15.98 \\
\hline Commission communication / notice & 585 & $2,398,606$ & 7 & 27 & $0.60 \%$ & 5.63 \\
\hline International agreement & 163 & $1,458,156$ & 3 & 11 & $0.92 \%$ & 3.77 \\
\hline
\end{tabular}

Corrigenda and correction density ratios for EU genres point to higher error incidence in directives and regulations, followed by Commission communications or notices, decisions and international agreements. In the last three genres (or rather a subgenre in the case of the latter, decisions of the European Parliament and of the Council), as well as for Commission directives, corrigenda were not found in every

${ }^{10}$ UNECE amendments to technical regulations, precisely the UN genre with the highest number of corrigenda in the corpus (13), were excluded from the calculation of average ratios, as they are only translated into French. 
year of the corpus. Table 6 includes subgenres of three key types of legal acts, as well as other genres with more than 100 texts and one million words of translation volume covered by the corpus. Some variations between subgenres are significant, particularly the high correction density ratios of directives and regulations of the European Parliament and of the Council in comparison to other subgenres.

Table 7. Changes in corrigenda and correction density ratios of EU genres with high translation volumes

\begin{tabular}{|l|r|r|r|r|r|r|}
\hline \multirow{2}{*}{} & \multicolumn{2}{|c|}{2005} & \multicolumn{2}{c|}{2010} & \multicolumn{2}{c|}{2015} \\
\cline { 2 - 7 } & Ratio 1 & Ratio 2 & Ratio 1 & Ratio 2 & Ratio 1 & Ratio 2 \\
\hline Regulation & $0.63 \%$ & 11.47 & $2.52 \%$ & 42.89 & $10.09 \%$ & 98.02 \\
\hline Commission Regulation & $0.57 \%$ & 12.75 & $1.90 \%$ & 41.96 & $7.77 \%$ & 128.27 \\
\hline Council Regulation & $1.25 \%$ & 2.73 & $11.96 \%$ & 82.58 & $8.51 \%$ & 30.55 \\
\hline $\begin{array}{l}\text { Regulation of the European } \\
\text { Parliament and of the Council }\end{array}$ & $3.85 \%$ & 57.36 & $10.61 \%$ & 24.21 & $26.92 \%$ & 77.98 \\
\hline Decision & $0.30 \%$ & 2.21 & $0.76 \%$ & 3.24 & $1.34 \%$ & 6.09 \\
\hline Commission Decision & $0.34 \%$ & 2.06 & $0.74 \%$ & 2.27 & $1.56 \%$ & 3.80 \\
\hline Decision of the European Council & $0.23 \%$ & 3.36 & $0.73 \%$ & 5.07 & $1.24 \%$ & 11.93 \\
\hline $\begin{array}{l}\text { Decision of the European } \\
\text { Parliament and of the Council }\end{array}$ & $0 \%$ & 0 & $1.19 \%$ & 10.95 & $0 \%$ & 0 \\
\hline Directive & $5.42 \%$ & 16.80 & $3.33 \%$ & 17.36 & $50.00 \%$ & 126.97 \\
\hline Council Directive & $15.00 \%$ & 51.46 & $6.25 \%$ & 17.70 & $62.50 \%$ & 165.40 \\
\hline $\begin{array}{l}\text { Directive of the European } \\
\text { Parliament and of the Council }\end{array}$ & $11.90 \%$ & 11.38 & $7.14 \%$ & 4.71 & $88.24 \%$ & 223.30 \\
\hline Commission Directive & $0.96 \%$ & 5.04 & $2.21 \%$ & 26.98 & $0 \%$ & 0 \\
\hline Commission communication / notice & $0 \%$ & 0 & $1.02 \%$ & 11.98 & $1.81 \%$ & 3.76 \\
\hline International agreement & $0 \%$ & 0 & $0 \%$ & 0 & $3.85 \%$ & 13.39 \\
\hline
\end{tabular}


Fernando Prieto Ramos: Facing Translation Errors...

Table 8. Years of publication of corrigenda and corrected documents

\begin{tabular}{|c|c|c|c|}
\hline & \multicolumn{3}{|c|}{ Year of corrigendum } \\
\hline $\begin{array}{l}\text { Year of document corrected } \\
\text { by corrigendum }\end{array}$ & 2005 & 2010 & 2015 \\
\hline 1978 & 1 & & \\
\hline 1992 & & & 1 \\
\hline 1993 & & & 1 \\
\hline 1997 & & 2 & \\
\hline 2001 & 1 & 1 & \\
\hline 2002 & & & 3 \\
\hline 2003 & 2 & 2 & \\
\hline 2004 & 14 & 1 & 3 \\
\hline 2005 & 15 & & \\
\hline 2006 & & 3 & 6 \\
\hline 2007 & & 1 & 2 \\
\hline 2008 & & 8 & 7 \\
\hline 2009 & & 25 & 9 \\
\hline 2010 & & 20 & 2 \\
\hline 2011 & & & 5 \\
\hline 2012 & & & 3 \\
\hline 2013 & & & 8 \\
\hline 2014 & & & 36 \\
\hline 2015 & & & 31 \\
\hline Total & 33 & 63 & 117 \\
\hline
\end{tabular}

Table 9. Overall corrigenda and correction density ratios of high-volume EU genres per year

\begin{tabular}{|c|c|c|c|c|c|c|}
\hline \multirow{2}{*}{} & \multicolumn{2}{|c|}{$\begin{array}{c}\text { TRANSLATION } \\
\text { VOLUME }\end{array}$} & \multicolumn{4}{c|}{ CORRIGENDA } \\
\cline { 2 - 7 } & \#D & Total words & \#D & \#C & Ratio 1 & Ratio 2 \\
\hline 2005 & 3,288 & $5,515,626$ & 40 & 82 & $0.61 \%$ & 7.43 \\
\hline 2010 & 2,204 & $6,580,897$ & 81 & 282 & $1.84 \%$ & 21.43 \\
\hline 2015 & 1,203 & $4,487,645$ & 128 & 405 & $5.32 \%$ & 45.12 \\
\hline
\end{tabular}


Diachronic changes (see Table $7^{11}$ ) show a general upward trend, with a few exceptions. However, annual correction density ratios must be interpreted with caution, as some indicators are affected by a disproportionate number of corrections of legal acts from earlier years, especially in 2015. Table 8 provides the breakdown of corrected acts and their years. As a methodological caveat, it would be impossible to predict the exact number of corrigenda that legal acts from a particular year may accumulate after their publication. However, most corrigenda refer to texts of the same or the previous year, and the proportion of corrected documents of this and other previous years is expected to be offset by further corrections of texts of the current year in subsequent years. The years of corrected texts in 2010 and especially 2015 deviate from this assumption, ${ }^{12}$ but this slight deviation is due to the sustained detection of errors in texts published after 2005, which, in turn, also confirms the correction trends identified in this study. Likewise, Table 9 corroborates the increasing level of error density as per the accumulated yearly totals for genres with large translation volumes, well above indicators obtained for the other institutions (albeit partial in the case of the UN). The possible causes for these results will be further discussed in the last section, whereas the analysis of specific error incidence levels per genre and year would require further scrutiny beyond the scope of this paper.

\subsection{Error types}

With a view to studying the most common types of errors corrected, all corrigenda containing between one and five corrections, i.e. 303

\footnotetext{
${ }^{11}$ With the entry into force of the Lisbon Treaty on $1^{\text {st }}$ December 2009, legal acts such as Council framework decisions were discontinued, while others, such as implementing regulations, were introduced. Therefore, not all legal act subgenres are found in all the years of the corpus. These were excluded from ratio calculations, since they would not be supported by sufficient translation volumes. The same applies to two 2015 corrigenda to a 2002 Decision of the Council and the Commission, for which there was no associated translation volume in the corpus.

${ }^{12}$ The most extreme case identified is that of the 2015 corrigenda to directives of the European Parliament and of the Council, which all refer to directives of previous years: 13 to 2014 directives, 22 to 2004-2013 directives and 1 to a 1997 directive.
} 
documents accounting for $87.83 \%$ of the total number of corrigenda (see Table 1), were analyzed in detail. A total of 388 corrections were verified and classified according to the error categories that emerged from the corpus analysis, as listed in Section 3. This number of corrections was considered statistically sufficient and highly representative of the translation issues detected and deemed to be worthy of a corrigendum. The inclusion of corrigenda issued for higher numbers of corrections (i.e. above five) would have not helped to discern the most frequent causes of corrigenda as in the case of corrigenda issued for single or few corrections.

Table 10. Groups of error types per year and organization

\begin{tabular}{|l|r|r|r|r|r|r|r|r|r|r|r|r|r|}
\hline & \multicolumn{4}{|c|}{ EU } & \multicolumn{4}{|c|}{ UN } & \multicolumn{4}{|c|}{ WTOtal } \\
\hline & 2005 & 2010 & 2015 & & 2005 & 2010 & 2015 & & 2005 & 2010 & 2015 & & \\
\hline Content reformulation corrections & 25 & 68 & 136 & 229 & 19 & 14 & 4 & 37 & 5 & 5 & 2 & 12 & 278 \\
\hline Minor formal corrections & 24 & 26 & 35 & 85 & 13 & 5 & - & 18 & 5 & 1 & 1 & 7 & 110 \\
\hline Total & 49 & 94 & 171 & 314 & 32 & 19 & 4 & 55 & 10 & 6 & 3 & 19 & 388 \\
\hline
\end{tabular}

Figure 3. Changes in groups of error types (totals)

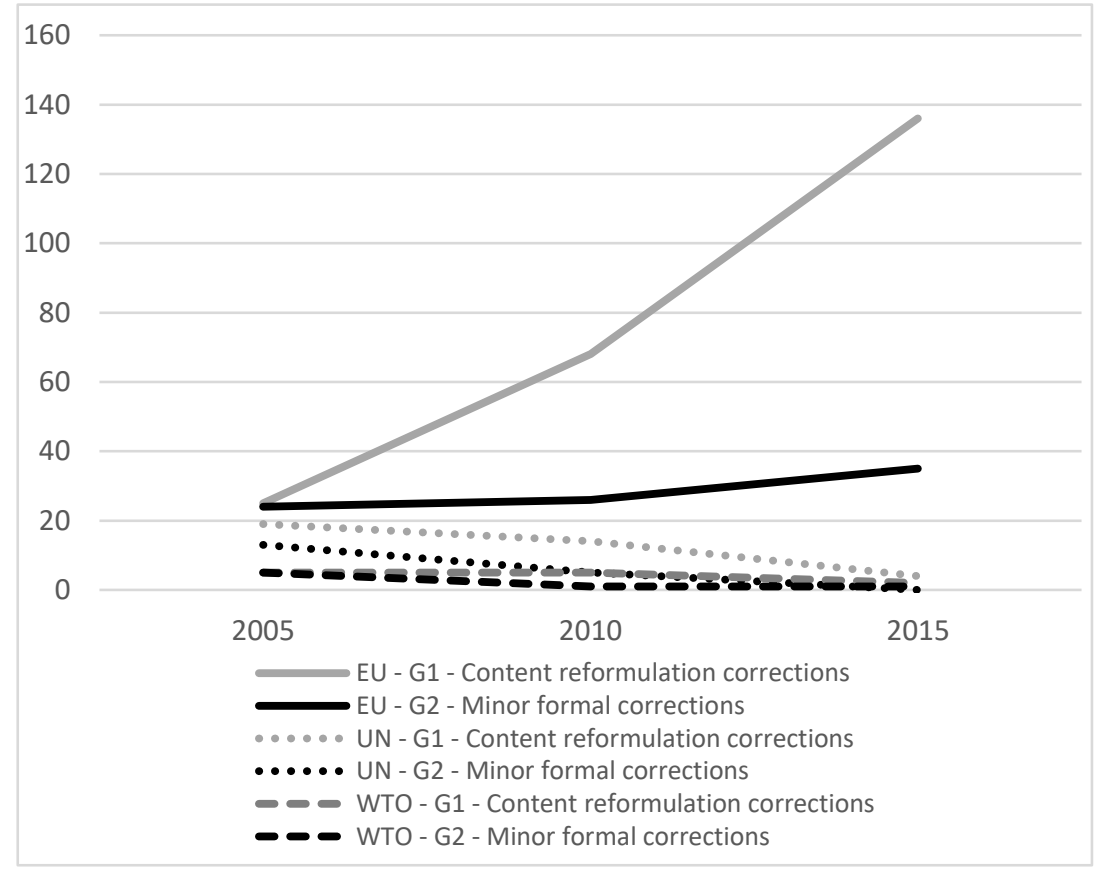


Figure 4. Changes in groups of error types (percentages)

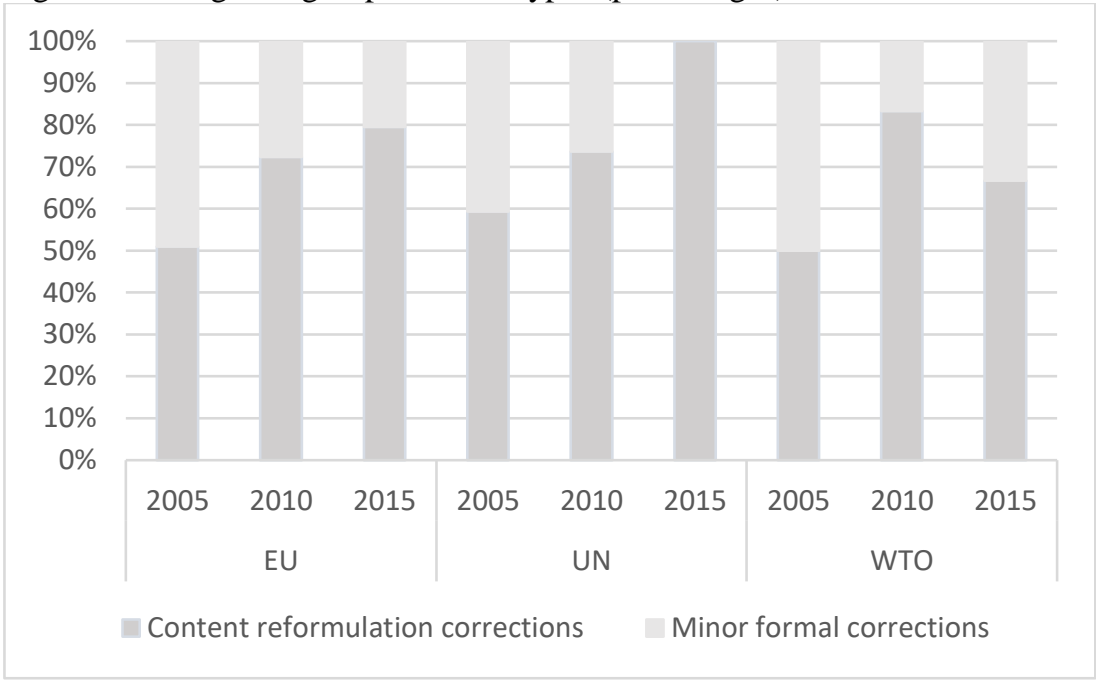

A first diachronic examination of error types (Table 10 and Figure 3) points to a higher frequency of content reformulation corrections (correction group 1 or "G1") compared to minor formal corrections (correction group 2 or "G2"). This trend intensifies over the 2005-2015 period, especially at the EU, from almost equal proportions in 2005 to almost $80 \%$ of errors of the first group in 2015 (see Figure 4).

However, once again, only EU figures are statistically robust to identify diachronic patterns of specific error types (Table 11 and Figures 5 and 6). Among content reformulation corrections, mistranslations that result in semantic inaccuracies are the main error category in all the institutions, followed by semantic distortions caused by incorrect terminology, unjustified omissions, unjustified additions and opposite meaning. The frequency order of error types is identical at the EU and the UN, with similar incidence levels in French and Spanish. In the EU corrigenda, the growth of all error types within the group of content reformulation corrections is equally pronounced, with a combined increase from 25 corrected errors in 2005 to 136 in 2015. 
Fernando Prieto Ramos: Facing Translation Errors...

Table 11. Error types per organization, year and target language

\begin{tabular}{|c|c|c|c|c|c|c|c|c|c|c|c|c|c|c|c|c|}
\hline & & & $\underset{\sim}{\infty}$ & Бे & ৪ & 용 & $\stackrel{\sim}{\infty}$ & ని & 은 & প্ল & $\bar{N}$ & $\stackrel{\infty}{\propto}$ & 士 & 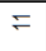 & 으 & $\mathbb{\infty}$ \\
\hline \multirow{10}{*}{ 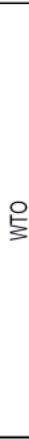 } & & & $\simeq$ & $r$ & - & $m$ & & - & $r$ & - & - & - & & $\sim$ & $\sim$ & 은 \\
\hline & \multirow{3}{*}{ ํํㄹ } & & $\sim$ & - & & - & & & - & & & - & & & & $m$ \\
\hline & & 妥 & - & & & - & & & - & & & - & & & & $\sim$ \\
\hline & & 出 & - & - & & & & & & & & & & & & - \\
\hline & \multirow{3}{*}{ 을 } & & مו & $m$ & & - & & - & - & & - & & & & & 0 \\
\hline & & $\underline{x}$ & $m$ & - & & - & & - & & & & & & & & $m$ \\
\hline & & 留 & $\sim$ & $\sim$ & & & & & - & & - & & & & & $m$ \\
\hline & \multirow{3}{*}{ 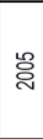 } & & in & $m$ & - & - & & & L 10 & - & & & & $\sim$ & $\sim$ & 으 \\
\hline & & $\underline{\alpha}$ & $m$ & - & - & - & & & + & - & & & & - & $\sim$ & $n$ \\
\hline & & 出 & $\sim$ & $\sim$ & & & & & - & & & & & - & & m \\
\hline \multirow{10}{*}{ ろ } & & & $\hat{m}$ & $\simeq$ & $F$ & $\infty$ & $\nabla$ & $\sim$ & $\stackrel{\infty}{-}$ & in & $m$ & $\nabla$ & $m$ & $\sim$ & - & 뇨 \\
\hline & \multirow{3}{*}{ 帤 } & & $\checkmark$ & & $\sim$ & - & - & & & & & & & & & $\nabla$ \\
\hline & & 㐍 & $\nabla$ & & $\sim$ & - & - & & & & & & & & & $\sigma$ \\
\hline & & 留 & & & & & & & & & & & & & & \\
\hline & \multirow{3}{*}{ 음 } & & $\stackrel{+}{\square}$ & $\nabla$ & 0 & $\sim$ & - & - & in & - & - & - & $\sim$ & & & 9 \\
\hline & & $\underset{\sim}{q u}$ & $r$ & $\nabla$ & $\sim$ & - & & & $m$ & - & & & $\sim$ & & & 으 \\
\hline & & 出 & $r$ & & $\nabla$ & - & - & - & $\sim$ & & - & - & & & & $\sigma$ \\
\hline & \multirow{3}{*}{ 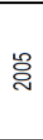 } & & 웅 & $\infty$ & $m$ & L & $\sim$ & - & $\stackrel{m}{\square}$ & $\nabla$ & $\sim$ & $m$ & - & $\sim$ & - & $\widetilde{m}$ \\
\hline & & 営 & 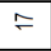 & 0 & $m$ & in & $\sim$ & - & 으 & $\sigma$ & & $m$ & - & $\sim$ & & $\bar{\sim}$ \\
\hline & & 邑 & $\sim$ & $\sim$ & & & & & $m$ & & $\sim$ & & & & - & 10 \\
\hline \multirow{10}{*}{ 岂 } & & & జి & $\mathbb{N}$ & 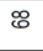 & $\stackrel{q}{q}$ & $\dot{N}$ & $\neq$ & 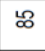 & I & ల & $\stackrel{m}{\simeq}$ & $F$ & $\sim$ & $r$ & 总 \\
\hline & \multirow{3}{*}{$\bar{\alpha}$} & & $\stackrel{g}{\dddot{m}}$ & F & f & $\bar{m}$ & $\simeq$ & $\sigma$ & p & $\infty$ & $=$ & $\infty$ & $\sigma$ & - & $m$ & $\Sigma$ \\
\hline & & $\stackrel{\mathscr{4}}{4}$ & I & న & $\stackrel{\circ}{\circ}$ & ㄱ. & in & $m$ & $=$ & - & in & $\sim$ & $\sim$ & - & & 20 \\
\hline & & 出 & $\approx$ & 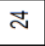 & ন & $F$ & $r$ & 0 & I & $r$ & 0 & 0 & $\sim$ & & $m$ & 8 \\
\hline & \multirow{3}{*}{ 음 } & & 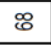 & $\bar{N}$ & $\widetilde{N}$ & $\stackrel{m}{\prime}$ & 0 & 0 & $\stackrel{\sim}{2}$ & in & or & $\nabla$ & in & - & $\sim$ & के \\
\hline & & $\underset{4}{\mathscr{x}}$ & স & o) & 으 & $\infty$ & م & $\sim$ & 응 & $\nabla$ & 0 & $\sim$ & \begin{tabular}{|ll}
$\infty$ \\
\end{tabular} & - & - & ณ \\
\hline & & 出 & স & $\simeq$ & $\simeq$ & in & - & $\nabla$ & $r$ & - & $m$ & $\sim$ & & & - & $\bar{\nexists}$ \\
\hline & \multirow{3}{*}{ 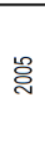 } & & $\stackrel{2}{\sim}$ & $r$ & 0 & $\nabla$ & 0 & $\sim$ & d & $F$ & $m$ & - & $\sim$ & in & $\sim$ & g \\
\hline & & 采 & $\stackrel{2}{2}$ & 0 & $\sigma$ & - & $m$ & - & $\stackrel{\circ}{\circ}$ & $\sigma$ & $\sim$ & - & $\sim$ & - & - & $\bar{m}$ \\
\hline & & 品 & 으 & - & $\sim$ & $m$ & $m$ & - & $\infty$ & $\sim$ & - & & & $\nabla$ & - & $\stackrel{\infty}{=}$ \\
\hline & & $\begin{array}{l}\text { 일 } \\
\text { 혼 } \\
\text { L }\end{array}$ & 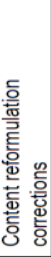 & 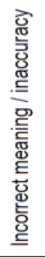 & 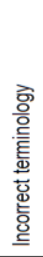 & 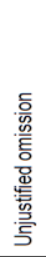 & 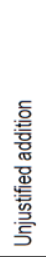 & 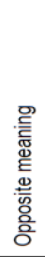 & 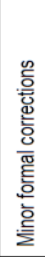 & 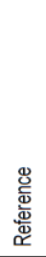 & 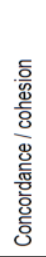 & 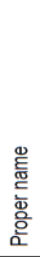 & 巻 & 愛 & 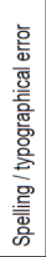 & 哭 \\
\hline
\end{tabular}




\section{Comparative Legilinguistics 41/2020}

Figure 5. Changes in error types at EU institutions (totals)

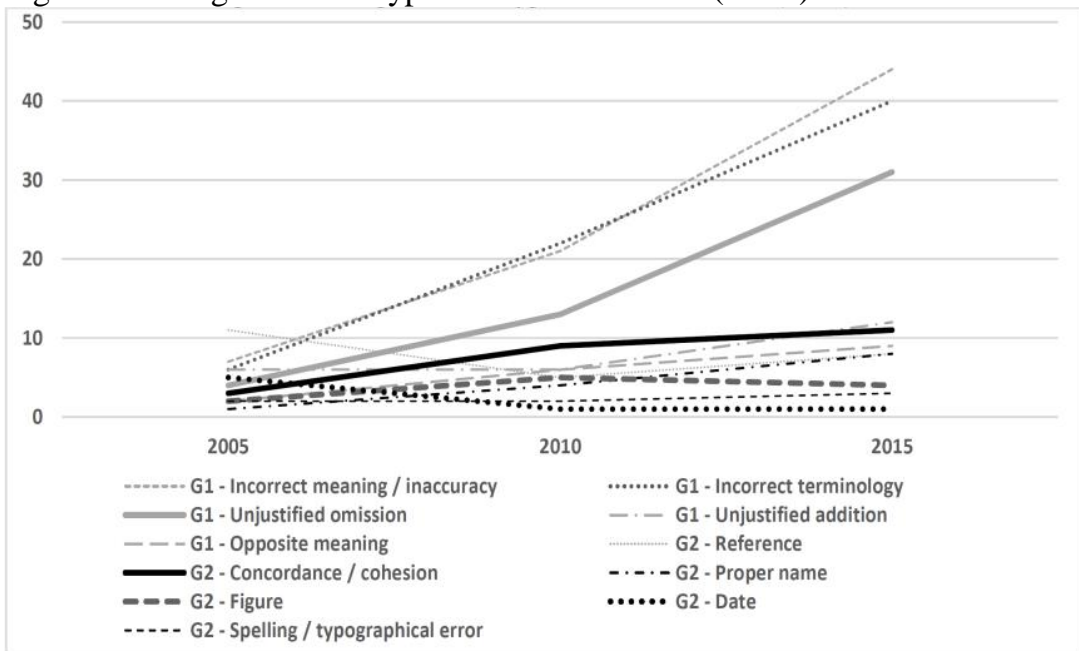

Figure 6. Changes in error types at EU institutions (percentages per year and language)

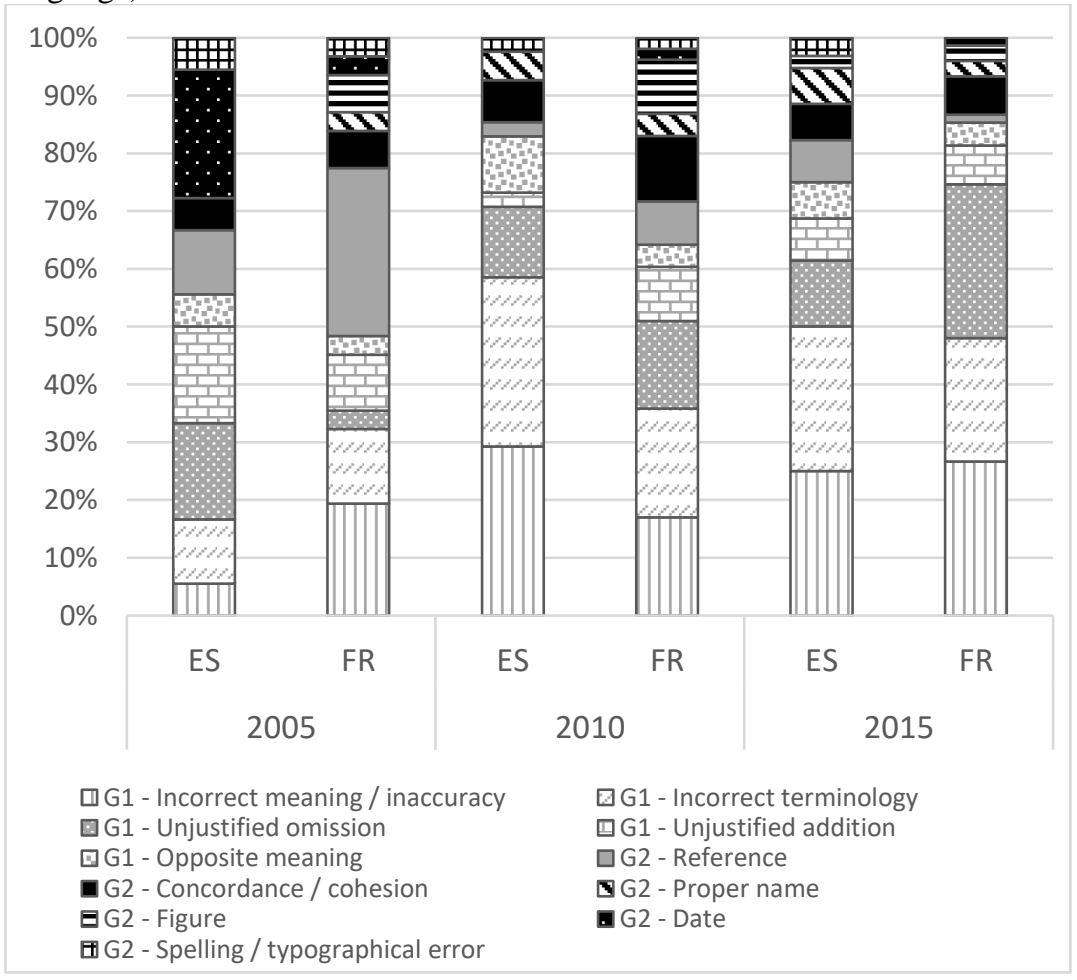


In contrast, minor formal corrections only grew slightly at the EU and decreased at the other two organizations. Error types of this group are more scattered than those of the first group. Overall, wrong references (e.g. numbers of provisions) are the most frequent formal error, followed by concordance and cohesion issues, mistakes in proper names, incorrect figures and dates. Finally, spelling and typographical errors are found at the bottom of the list. This seems to align to the general principle of avoiding corrigenda to correct very minor errors. In fact, in only two of the 11 cases of the last category, the spelling or typographical errors were the only reason for issuing their corresponding corrigenda (i.e. the only single-correction corrigenda in this subgroup) and they were precisely the only cases that entailed sensitive meaning distortions: a change of symbol in a formula ("--" instead of the original " $\times$ " in Annex IX of Commission Delegated Regulation (EU) 2015/1187 in Spanish) and an incorrect measurement unit (" $10 \mathrm{~mW} / \mathrm{kHz}$ " instead of " $10 \mathrm{~mW} / \mathrm{MHz}$ " in Commission Decision 2005/513/EC in French). In two other cases, the main reason was a spelling mistake in the name of the President of the European Parliament ("J Busek" in French and "J. Busek" in Spanish, instead of "J. Buzek", in Regulation (EC) No 67/2010 of the European Parliament and of the Council). The second corrections in these corrigenda were a missing full stop after the date at the end of the text in French, and a missing article in the same date in Spanish, two problems that would not have probably been considered serious enough in isolation for a corrigendum to be issued. The other punctuation mistake detected in the corrigenda corpus (another missing full stop) is included in a list with two more serious reformulation corrections (corrigendum to Regulation (EU) No 652/2014 of the European Parliament and of the Council in Spanish).

\subsection{Severity of corrected errors}

The above examples recall a key question: to what extent are minor formal errors problematic in light of their impact on the intended meaning and the potential consequences of these meaning distortions? As suggested in Sections 2 and 3, in institutional contexts, and more generally, the severity of translation errors tends to be associated with 
their impact on the semantic components of a text, such as central ideas or concepts. Institutional guidelines on corrigenda do not elaborate much on error severity, but associate minor formal corrections with obvious and unimportant errors. According to the DGT's tender specifications for outsourced translations (OMNIBUS-15) of $1^{\text {st }}$ July 2016, errors are "classified according to their severity as 'lowrelevance' or 'high-relevance' errors" (Strandvik 2017: 125), where the latter category is understood as an error that "seriously compromises the translation's usability" (DGT 2016: 11). In the case of legal documents, this means that serious errors may affect the scope or effects of the texts. Along these lines, to compare the severity of error types, each identified error was assigned a degree of semantic (or meaning deviation) impact according to the following scale:

- Level 0: no semantic impact, i.e. the error is obvious and does not affect the content of the segment. For example:

- "Nada de lo dispuesto en el presente Convenio menoscabarán $[\ldots]$ " instead of "menoscabará [...]" (our emphasis) for "Nothing in this Convention shall affect [...]" (wrong subject-verb agreement in UN report A/59/766 in Spanish);

- "déclaration de conformité avec ce critère" instead of "à ce critère" (our emphasis) for "declaration of compliance with this criterion" (incorrect preposition in Commission Decision 2005/360/EC in French).

- Level 1: limited semantic impact, i.e. the error causes a change in meaning but the affected element does not significantly impact the overall scope or effects of the text as a whole considering the relevance and context of the segment. For example:

- "programme de travail pluriannuel" instead of "programme de travail annuel" for "annual work programme" (inaccuracy in Regulation (EU) No 1077/2011 of the European Parliament and of the Council in French);

- " 1 " de septiembre de 2005 " instead of " 1 " de septiembre de 2004" (error in the first of two references to the effective date of changes to a WTO schedule of tariff concessions in WT/Let/489 in Spanish). 
- Level 2: serious semantic impact, i.e. the error may lead to a change in scope or understanding of important elements of the text, such as key concepts, definitions, conditions or deadlines, and may even involve legal, political or economic consequences. For example:

- "carezca de ánimo de lucro" instead of "tenga ánimo de lucro" for "organised on a for-profit basis" (opposite meaning in Directive 2014/26/EU of the European Parliament and of the Council in Spanish);

- “990,94 millions de dollars d'intérêts" instead of "990 941 dollars d'intérêts" for " $\$ 990,941$ in interest" (wrong figure in UN financial report A/65/5/Add.9 in French).

To limit subjectivity and ensure consistency in the application of this scale, the severity analysis was double-checked with a second validator and borderline cases (few) were further reviewed. Overall, as expected, the average impact score of content reformulation corrections (1.57) was higher than that of minor formal corrections (1.31), but not by far (see Table 12). The main differences between institutions are the higher impact level of the first group at the WTO (1.75), and of the second group at the UN (1.44 compared to 1.14 at the WTO). This seems to confirm that, as a rule, corrigenda concerning errors of low semantic impact are strictly avoided at the UN according to its editorial guidelines, in contrast with the explicit inclusion of "non-substantive" corrections in the WTO guidelines. Interestingly, the only typing error of level 0 severity identified in a UN corrigendum ("nos e" instead of "no se" in A/59/766/CORR.4 in Spanish) appears in a list with four other corrections. At the same time, reissues for technical reasons (not considered for the severity statistics) may correct errors of significant semantic impact, as illustrated in Section 2 (examples of opposite meaning and unjustified omission).

It is not surprising that spelling and typographical errors scored the lowest severity level (0.60) together with concordance and cohesion issues (0.59). Both concentrate the largest proportion of level 0 errors (see Table 13). However, a few mistakes of these types caused significant semantic distortions, such as the two typographical errors that triggered single-correction corrigenda in the EU (see Section 4.3). 
Table 12. Severity of errors expressed in levels of semantic impact

\begin{tabular}{|l|c|c|c|c|}
\hline & EU & UN & WTO & Overall \\
\hline Content reformulation corrections & $\mathbf{1 . 5 6}$ & $\mathbf{1 . 5 4}$ & $\mathbf{1 . 7 5}$ & $\mathbf{1 . 5 7}$ \\
\hline Opposite meaning & 2.00 & 2.00 & 2.00 & 2.00 \\
\hline Unjustified omission & 1.94 & 2.00 & 1.33 & 1.92 \\
\hline Unjustified addition & 1.67 & 1.00 & - & 1.57 \\
\hline Incorrect meaning / inaccuracy & 1.43 & 1.58 & 1.86 & 1.48 \\
\hline Incorrect terminology & 1.29 & 1.27 & 2.00 & 1.30 \\
\hline Minor formal corrections & $\mathbf{1 . 2 9}$ & $\mathbf{1 . 4 4}$ & $\mathbf{1 . 1 4}$ & $\mathbf{1 . 3 1}$ \\
\hline Proper name & 1.62 & 2.00 & 2.00 & 1.72 \\
\hline Figure & 1.64 & 2.00 & - & 1.71 \\
\hline Reference & 1.71 & 1.80 & 1.00 & 1.70 \\
\hline Date & 1.57 & 1.00 & 1.50 & 1.45 \\
\hline Spelling / typographical error & 0.86 & 0.00 & 0.00 & 0.60 \\
\hline Concordance / cohesion & 0.57 & 0.33 & 2.00 & 0.59 \\
\hline
\end{tabular}

Table 13. Distribution of severity levels per error type

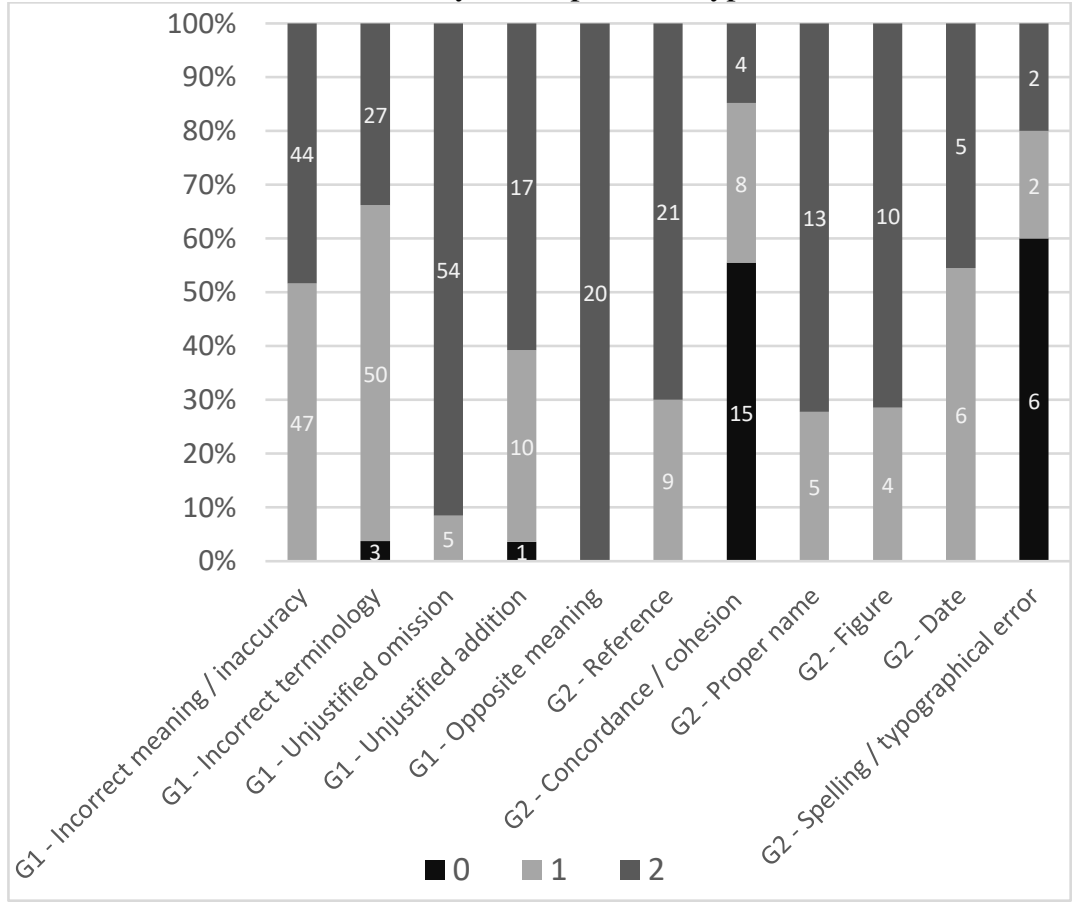


At the other extreme, the most serious semantic impact and the highest proportion of level 2 errors are found in content reformulation error types, with averages of between 2 (opposite meaning) and 1.48 (incorrect meaning or inaccuracy). Incorrect terminology scored an average severity level of 1.30, including more errors of limited than serious semantic distortion impact. Error types in the group of minor formal corrections, except for spelling or typographical errors and concordance or coherence issues, were often more serious, with average severity levels of between 1.45 (dates) and 1.72 (proper names). These findings serve to debunk ideas that systematically associate minor formal corrections on the textual surface with minor semantic impact and limited potential consequences.

\section{Discussion and conclusions}

From procedural, pedagogical and managerial perspectives, corrigenda and the corrections they explain are of keen interest to institutional language services in a context in which (1) their reputation remains linked to expectations of quality, while (2) their exposure to scrutiny (and accountability) has been accentuated by enhanced text accessibility and search tools, and (3) their workflows have been adapting to growing trends in automation and outsourcing. Over the 2005-2015 period examined here, EU institutions have been the most explicitly concerned about correction processes, particularly as a result of the addition of official languages to the EU's directly applicable legislation, which accounts for a high proportion of translation work in that context. In contrast, the UN, with a much more limited production of binding instruments, has seen a parallel reduction of corrigenda and an increase in the number of reissues for technical reasons, which are also used to correct translation errors as illustrated in this study. Given the lack of traceability of the initial translation in these cases, the UN model of reissues would be impracticable for EU legislation due to the prevailing need to preserve transparency and legal certainty. Nonetheless, predictability, as a pillar of legal certainty, is challenged by the high number of EU corrigenda that introduce semantic adjustments with retroactive effects after the publication of EU legal 
acts. This has been the object of criticism on the basis that "meaningchanging corrigenda are amendments in a material sense, which can be applied only prospectively, and even then, with due respect for acquired rights and the legitimate expectations of the individuals concerned" (Bobek 2009: 962).

The fact that the UN genres most frequently rectified by corrigenda and reissues for technical reasons are non-binding texts (e.g. reports, resolutions, agendas and budgets) and that the language of the original texts is normally indicated in UN documents provides more leeway for correction processes and reduces legal risks in that organization. The same applies to the WTO, with only three official languages, smaller translation volumes and very few corrigenda, all of them clearly identified as such for both substantive or non-substantive corrections. The most affected texts in this organization are notifications by Member States, but with an impressively low density of corrections.

Both legal and linguistic considerations are therefore key to interpreting our quantitative findings. The higher incidence of errors detected in EU documents actually means that the system as a whole is effective in handling an overwhelming volume of translation produced by several institutional languages services: errors that should have been spotted through quality control before publication are corrected ex post, thus preventing more serious consequences at a later stage. What represents an initial failure of quality assurance processes is subsequently repaired through corrective actions with the support of legal services. Considering the massive volume of EU translation and the challenges faced in that context since the mid-2000s (Strandvik 2018), the number of corrections can be deemed acceptable, while also providing a compelling reminder of the acute need for quality assurance in situations of strain and productivity pressure for language services.

The types and severity of errors corrected confirm that, in all the institutions examined, meaning-distorting content reformulation corrections are the most common, and on the increase, while minor formal corrections seem to be quantitatively stable and their semantic impact severity is often comparable to content reformulation errors. The only exceptions are spelling or typographical mistakes and grammarrelated concordance or cohesion problems, such as overlooked repetitions (often "copy-paste errors") and agreement between sentence components, more commonly attributable to insufficient attention or quality control. These error types, however, rarely trigger single- 
correction corrigenda unless they have a significant semantic impact (e.g. wrong symbol or measurement unit in a formula). Two conclusions derive from these findings: (1) the nature of minor formal corrections on the textual surface cannot be systematically associated with obvious or unimportant errors; they might not be obvious to detect, and they may alter sensitive elements of the text; and (2) in their application of correction principles, language and legal services are guided by semantic impact severity regardless of the origin of the error, and hence irrelevant stylistic or typographical corrections are avoided as the sole reason to issue a corrective document.

As regards diachronic patterns, the soaring number of corrections in EU texts emerges as a matter of concern, and calls for specific attention. Apart from the high scrutiny and exposure of EU legal acts and the increasing number of EU languages, other systemic factors may partly explain the upward trend. One of them is the complexity of the ordinary legislative procedure introduced by the Lisbon Treaty, as also suggested by the correction ratios identified per genre and subgenre. The multiple readings of legislative proposals and the enlarged number of actors involved in the process may contribute to the risk of inaccuracies or inconsistencies. As highlighted by the DGT, an added factor behind the "increasing number of corrigendum requests in recently adopted legal acts" might be the heightened awareness of the corrigenda-handling process as a result of the DGT's empowerment of 2008 (European Commission 2012: 31). This seems to be confirmed by the gradual increase in corrigenda to documents of a broader time spectrum in our 2010 and 2015 results. However, this only accounts for part of the overall growth of corrections.

From a translation management angle, the question arises whether and to what extent the adaptation of working conditions derived from post-enlargement resource constraints also had an impact on error patterns. More particularly, as elicited through interviews conducted at the same institutions, the EU outsourcing model privileging large translation service providers, rather than accredited individual external translators as in the UN and the WTO, entails higher risks to quality due to less predictable quality control needs for individual translations (Prieto Ramos 2017: 71). This outsourcing model would require reinforced quality assurance measures in order to reduce risks, something that DGT has recently addressed as part of its revamped Quality Management Framework (DGT 2014 in Strandvik 2018) and its Translation Quality Guidelines (DGT 2015). Other EU 
institutions, such as the Council of the EU (see Hanzl and Beaven 2017), have also revised their quality assurance practices along similar lines. The impact of these new approaches is yet to be examined.

The same goes for the impact of new technological tools in all institutional language services. While some computer applications may help to detect errors and inconsistencies, the expansion of neural machine translation is also bringing rapid change to workflows and working methods. In a context in which institutional translation management models need to integrate these new variables (i.e. interaction between in-house and external human and machine inputs and outputs) into risk assessment equations and quality assurance policies, it will be critical to monitor trends in the nature and severity of errors spotted or unnoticed through the production chain. As regards translator training and professional development, the shift from traditional translation and revision profiles to specialized post-editors and quality controllers will only stimulate further interest in analyses of error types and how they surface in corrigenda.

\section{Acknowledgments}

I would like to thank Albert Morales for his assistance with data extraction and processing, as well as all institutional informants for their valuable cooperation, and Diego Guzmán for his technical support.

\section{References}

Baaij, Cornelis J. W. 2012. Fifty Years of Multilingual Interpretation in the EU. In The Oxford Handbook of Language and Law, eds. Peter M. Tiersma and Lawrence M. Solan, 217-231. Oxford: Oxford University Press.

Bobek, Michal. 2009. Corrigenda in the Official Journal of the European Union: Community Law as Quicksand. European Law Review 34: 950-962.

Bobek, Michal. 2011. The Multilingualism of European Union Law in the National Courts: Beyond the Textbooks. In Linguistic 
Diversity and European Democracy, eds. Anne Lise Kjær and Silvia Adamo, 123-142. Aldershot: Ashgate.

Byrne, Jody. 2007. Caveat translator: Understanding the legal consequences of errors in professional translation. Journal of Specialised Translation 7: 2-24.

Council of the EU. 2015. Manual of precedents for acts established within the Council of the European Union. Brussels: Council of the EU.

Dengler, Pablo. 2010. Derecho de la UE y multilingüismo: El problema de las divergencias entre versiones lingüísticas. In Translating Justice / Traducir la Justicia, eds. Icíar Alonso Araguás, Jesús Baigorri Jalón and Helen J. L. Campbell, 83-98. Granada: Comares.

DGT. 2014. DGT Quality Management Framework. Document Ref. Ares(2014)799428.

DGT. 2015. DGT Translation Quality Guidelines. Document Ref. Ares(2015)5389770.

DGT. 2016. Strategic Plan 2016-2020. Document Ref. Ares(2016)1329034.

Drugan, Joanna. 2013. Quality in Professional Translation: Assessment and Improvement. London: Bloomsbury.

European Commission. 2008. Memorandum to the Commission from the President in agreement with Mr Orban. Empowerment to correct errors, including minor errors, in translations of acts adopted by the Commission. Document Ref. SEC(2008) 2397.

European Commission. 2010. Lawmaking in the EU Multilingual Environment. Luxembourg: Publications Office of the European Union.

European Commission. 2012. Quantifying Quality Costs and the Cost of Poor Quality in Translation. Luxembourg: Publications Office of the European Union.

Hanzl, Jan, and John Beaven. 2017. Quality assurance at the Council of the EU's Translation Service. In Quality Aspects in Institutional Translation, eds. Tomáš Svoboda, Łucja Biel and Krzysztof Łoboda, 139-153. Berlin: Language Science Press.

Prieto Ramos, Fernando. 2017. The evolving role of institutional translation service managers in quality assurance: Profiles and challenges. In Quality Aspects in Institutional Translation, eds. Tomáš Svoboda, Łucja Biel and Krzysztof Łoboda, 59-74. Berlin: Language Science Press. 
Prieto Ramos, Fernando, and Lucie Pacho Aljanati. 2018. Comparative Interpretation of Multilingual Law in International Courts: Patterns and Implications for Translation. In Institutional Translation for International Governance: Enhancing Quality in Multilingual Legal Communication, ed. Fernando Prieto Ramos, 181-201. London: Bloomsbury.

Strandvik, Ingemar. 2017. Evaluation of outsourced translations: State of play in the European Commission's Directorate-General for Translation (DGT). In Quality Aspects in Institutional Translation, eds. Tomáš Svoboda, Łucja Biel and Krzysztof Łoboda, 123-137. Berlin: Language Science Press.

Strandvik, Ingemar. 2018. Towards a More Structured Approach to Quality Assurance: DGT's Quality Journey. In Institutional Translation for International Governance: Enhancing Quality in Multilingual Legal Communication, ed. Fernando Prieto Ramos, 51-62. London: Bloomsbury.

United Nations. 1983. United Nations Editorial Manual. New York: United Nations. 